\title{
When to sample in an inaccessible landscape: a case study with carabids from the Allgäu (northern Alps) (Coleoptera, Carabidae)
}

\author{
Ingmar Harry', Claudia Drees², Hubert Höfer ${ }^{3}$, Thorsten Assmann ${ }^{4}$ \\ I ABL, Nägeleseestraße 8, D-79102 Freiburg, Germany 2 Tel Aviv University, George S. Wise Faculty of Life \\ Sciences, Department of Zoology, The National Collections of Natural History, Tel Aviv 69978, Israel 3 Natural \\ History Museum Karlsruhe (SMNK), Erbprinzenstraße 13, D-76133 Karlsruhe, Germany 4 Institute of Ecology \\ and Environmental Chemistry, Leuphana University Lüneburg, D-21335 Lüneburg, Germany \\ Corresponding author: Ingmar Harry (harry@abl-freiburg.de) \\ Academic editor: H. Turin | Received 4 December 2009 | Accepted 22 April 2010 | Published 20 May 2011 \\ Citation: Harry I, Drees C, Höfer H, Assmann T (2011) When to sample in an inaccessible landscape: a case study \\ with carabids from the Allgäu (northern Alps) (Coleoptera, Carabidae). In: Kotze DJ, Assmann T, Noordijk J, Turin H, \\ Vermeulen R (Eds) Carabid Beetles as Bioindicators: Biogeographical, Ecological and Environmental Studies. ZooKeys \\ 100: 255-271. doi: 10.3897/zookeys.100.1531
}

\begin{abstract}
While pitfall trapping is generally accepted as the standard method for sampling carabid beetles, this method has rarely been used in mountain ecosystems, mainly due to the high labour intensity it involves. As part of a research project in the German Alps, we investigated the phenologic appearance of adult carabid beetles in mountain ecosystems along with the consequences of possible reductions in sampling periods. Our results show that an early activity peak among carabids is predominant in mountain ecosystems. However, there are differences among species: the main group of species showed the highest activity directly after snow melt, a second group showed a delayed activity peak and a small third group had no clear peak at all. Based on this study, we recommend two fortnightly sampling periods as a minimum for a sampling programme: one immediately after snow melt, and a second sampling period after a pause of two weeks.
\end{abstract}

\section{Keywords}

Carabidae, mountain ecosystems, phenology, sampling effort, pitfall traps 


\section{Introduction}

Since harsh abiotic conditions along with high spatial heterogeneity dominate mountain ecosystems, in stark contrast to the surrounding landscapes, alpine sites are interesting for ecological and biogeographical research (Lomolino 2001). This is especially true for questions related to environmental changes (e.g. climate change or change of land use) with mountains serving as suitable model ecosystems (Haslett 1997).

Carabidae is a group often used as indicator and/or model taxon (Dufrene and Legendre 1997; Rainio and Niemela 2003; Szyszko et al. 2000). They have also been used to help understand fundamental ecological processes in mountain landscapes (e.g. Franz 1970; Holdhaus 1954).

Nevertheless, very few investigations have been carried out using pitfall traps in high elevation mountain areas (cf. Brandmayr et al. 2003a; Gesellschaft für Angewandte Carabidologie 2009), although this method is otherwise very widely used. The most cited reason given for the limited use of this method is that of labour intensity due to the difficulty in accessing these often remote study areas. To reduce the time invested, depending on the research issue, it might be possible to shorten the sampling period. A likely side effect will be a lower number of specimens captured, leading most probably to a reduction in the number of recorded species. An understanding of the relationship between reduced sampling effort and number of recorded species is needed as a basis for decisions regarding timing and frequency of sampling, especially in the context of long-term monitoring.

Annual rhythms of activity and reproduction have been a major issue in carabidology, dating back to Larsson's pioneering work in this field (Larsson 1939). His classification of carabids' annual rhythms was elaborated upon and modified by other carabidologists (Lindroth 1949; Thiele 1977), and the importance of reproductive behaviour as a life history trait in carabids was emphasized by den Boer and van Dijk (1998) and Paarmann (1979). Many studies have dealt with the relationship between activity patterns and habitat preference, and these studies have lead to a better understanding of distribution trends and specific habitat adaptations of carabids (Lys and Nentwig 1991; Riddick and Mills 1995; den Boer and van Dijk 1996; Matalin 1997; Fadl and Purvis 1998; Traugott 1998; Hutchison 2007).

For mountain ecosystems, literature covering the reproductive seasonality of ground beetles is sparse. There are some works dealing with the phenology of carabids at high altitudes (Lang 1975; De Zordo 1979a, b; Janetschek et al. 1987; Gereben 1995; Ottesen 1996; Sota 1996; Hosoda 1999; Sharova and Khobrakova 2005). Many of these report a shortened activity period, but none of them examine possibilities and consequences of reduced sampling time.

A long-term research project in the "Allgäuer Hochalpen" in the German Alps was conducted in an area protected under the European Union "Habitats Directive". The project aimed at assessing effects of intensive long-term grazing of sheep and associated grazing regime changes after extensive cattle pasturing in 2000. In this project, intensive sampling of epigeic arthropods was performed over 6 years using pitfall traps. In this 
paper we focus on the seasonal activity of carabid beetles, primarily in the subalpine, but also in the alpine research area. We (1) describe the phenology of carabid beetles in the mountain ecosystems; and (2) investigate the consequences of reducing the number of sampling periods in order to present an optimized sampling scheme for recording the maximum number of species in subalpine and alpine altitudes of the northern Alps.

\section{Methods}

\section{Study area}

The mountain pasture "Alpe Einödsberg" $\left(10,28^{\circ} ; 47,32^{\circ}\right)$ is located in the German Alps (south-western Bavaria) and is part of the "Allgäuer Hochalpen", an area protected under the European Union "Habitats Directive". The study area ranges in altitude from 1400 to 2000 meters above sea level (m a. s. l). and encompasses a total area of about $2 \mathrm{~km}^{2}$. Most of the predominantly west-facing slopes consist of meadows dominated by Nardus stricta. Woodland belts dominated by Norway spruce (Picea abies) and krummholz made up of Alnus viridis, occur throughout the pasture zone (Fig. 1). There is a $2 \mathrm{~km}$ ridge running north-south along the upper segment of the pasture. Additional information about the vegetation and geology is given in Höfer et al. (2008), Höfer et al. (in press) and SMNK 2009.

In 2005, sampling was conducted at 25 sites. Sampling was focused on Nardus stricta-dominated meadows on slopes and on ridge sites dominated by Deschampsia cespitosa. In addition, several forest sites and open sites at lower altitudes were sampled (Table 1).

\section{Sampling}

At each sampling site, 6 pitfall traps (with a diameter of $6 \mathrm{~cm}$, filled with $10 \%$ acetic acid, $90 \%$ water) were installed at a distance of $6 \mathrm{~m}$ from each other. In order to protect the traps from heavy rain and from cattle-related damage, traps were placed in a metal tube with a transparent plastic cover (Lederbogen et al. 2004).

The pitfall traps were installed at the beginning of June, just after the first snowmelt at the ridge, and were removed at the end of September 2005 after a period of snow cover. Traps were emptied every fortnight. Altogether, there were 8 sampling periods, these were numbered chronologically $\left(1\right.$ : June $5^{\text {th }}-18^{\text {th }}, 2$ : June $19^{\text {th }}-$ July $2^{\text {nd }}, 3$ : July $3^{\text {rd }}-$ July $18^{\text {th }}$, 4: July $19^{\text {th }}-$ August $1^{\text {st }}$, 5: August $2^{\text {nd }}-$ August $15^{\text {th }}$, 6: August $16^{\text {th }}$ - August $29^{\text {th }}, 7$ : August $30^{\text {th }}-$ September $12^{\text {th }}, 8$ : September $13^{\text {th }}-$ September $26^{\text {th }}$ ).

Carabids were identified to species level; the nomenclature of the species follows Müller-Motzfeld et al. (2004). Not all specimens of Bembidion incognitum and B. deletum could be identified to species level and they were thus treated as 'Bembidion incognitum/deletum' in Table 2. 


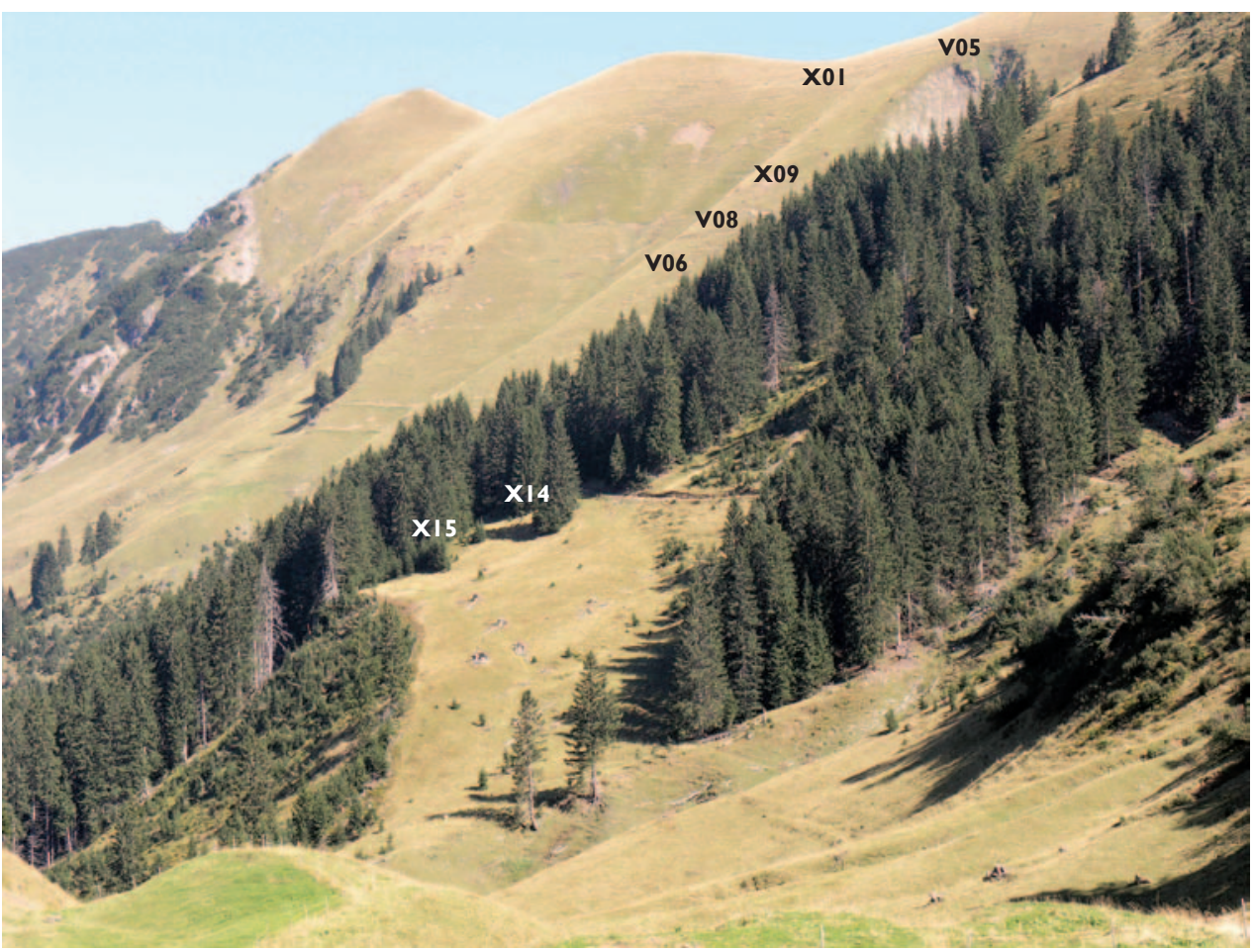

Figure I. The study area "Alpe Einödsberg". Position of some sampling sites is indicated.

\section{Data analysis}

In order to compare species and sites with different numbers of individuals, percentage of total catches per sampling period were used. Total number of species per sampling period and mean number of species per site and sampling period were compared.

For comparison of phenology at different altitudes, the sites were divided into three altitude classes $(<1600,1600-1850,>1850 \mathrm{~m}$ a. s. 1.) which contained similar numbers of sites. The weighted mean phenological appearance was calculated for each species per altitude class. Differences among classes were tested with a t-test, whereby we only used data for species which occurred at each sampling site and for which at least 10 individuals per class were found. Differences in phenological appearance in the traits: 'hindwing development' and 'body length' were also tested. For 'hindwing length' the groups 'brachypter', 'dimorphic' and 'macropterous' were tested using a t-test; for body size, species were grouped into 7 classes (mean body length < 3 mm, 3-6 mm, 6-9 mm, 9-12.5 mm, 12.5-20 mm, 20-27 mm, >27 $\mathrm{mm}$ ) and a Spearman rank correlation was performed. Bonferroni corrections were conducted for each test family. For t-tests, data were checked for normality with Shapiro-tests. 
Table I. Sample sites. Altitude is given in $\mathrm{m}$ a. s. 1., incline and exposition in ${ }^{\circ}$.

\begin{tabular}{|c|c|c|c|c|}
\hline site & type & altitude & inclination & exposition \\
\hline V02 & ridge & 1875 & 12 & 180 \\
\hline V03 & ridge & 1880 & 21 & 210 \\
\hline V05 & ridge & 1885 & 29 & 275 \\
\hline V06 & slope & 1751 & 34 & 255 \\
\hline V08 & slope & 1776 & 35 & 260 \\
\hline V10 & slope & 1809 & 38 & 235 \\
\hline V11 & slope & 1703 & 27 & 250 \\
\hline V16 & surface erosion & 1790 & 35 & 230 \\
\hline V23 & sucession Alnus viridis & 1765 & 38 & 300 \\
\hline $\mathrm{X} 01$ & ridge & 1884 & 25 & 250 \\
\hline $\mathrm{X} 03$ & slope & 1896 & 33 & 270 \\
\hline X04 & ridge & 1980 & 32 & 280 \\
\hline $\mathrm{X} 05$ & ridge & 1993 & 9 & 250 \\
\hline X07 & slope & 1781 & 39 & 265 \\
\hline X08 & slope & 1786 & 35 & 260 \\
\hline $\mathrm{X} 09$ & slope & 1798 & 37 & 255 \\
\hline $\mathrm{X} 10$ & ridge & 1911 & 28 & 275 \\
\hline $\mathrm{X} 11$ & slope & 1751 & 34 & 300 \\
\hline $\mathrm{X} 13$ & Alnus viridis krummholz & 1750 & 38 & 320 \\
\hline $\mathrm{X} 14$ & forest & 1565 & 24 & 270 \\
\hline $\mathrm{X} 15$ & forest & 1550 & 34 & 285 \\
\hline $\mathrm{X} 17$ & open, low altitude & 1434 & 24 & 245 \\
\hline $\mathrm{X} 18$ & open, low altitude & 1476 & 31 & 270 \\
\hline $\mathrm{X} 20$ & slope & 1720 & 31 & 300 \\
\hline $\mathrm{X} 21$ & ridge & 1990 & 5 & 280 \\
\hline
\end{tabular}

Species accumulation curves (also called sample-based rarefaction curves) were used to compare sampling effort and species richness measures (Buddle et al. 2005; Duelli et al. 1999; Gotelli and Colwell 2001; Ugland et al. 2003). Rarefaction curves for the whole dataset and for each unique sampling period were calculated using Kobayashi's formula (Kobayashi 1974) in the R package 'vegan' (Oksanen et al. 2008; R Development Core Team 2008).

Several reduced datasets with data from two sampling periods were produced. Rarefaction curves and species number per site were compared across the whole dataset, single sampling periods and different combinations of sampling periods.

To understand how the assemblage of carabid beetle species could be represented in the case of a reduced sampling effort we computed a dissimilarity matrix based on Bray-Curtis distances. For this analysis, species numbers were standardised to percentage-data of total species numbers per site and square-root-transformed. Based on this matrix a hierarchical cluster procedure was conducted using Ward's minimum variance method. 


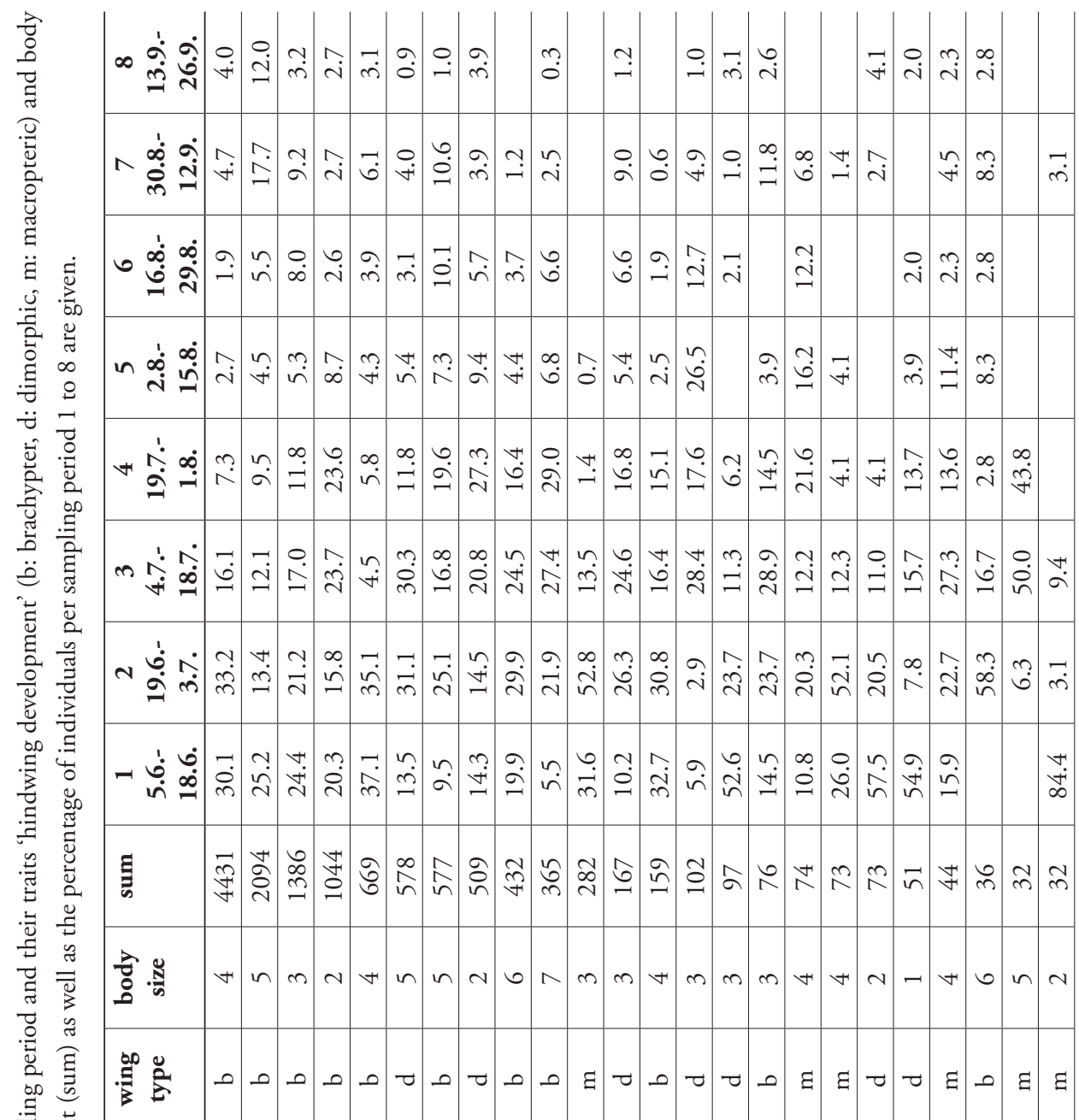

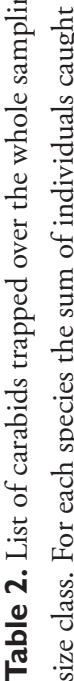

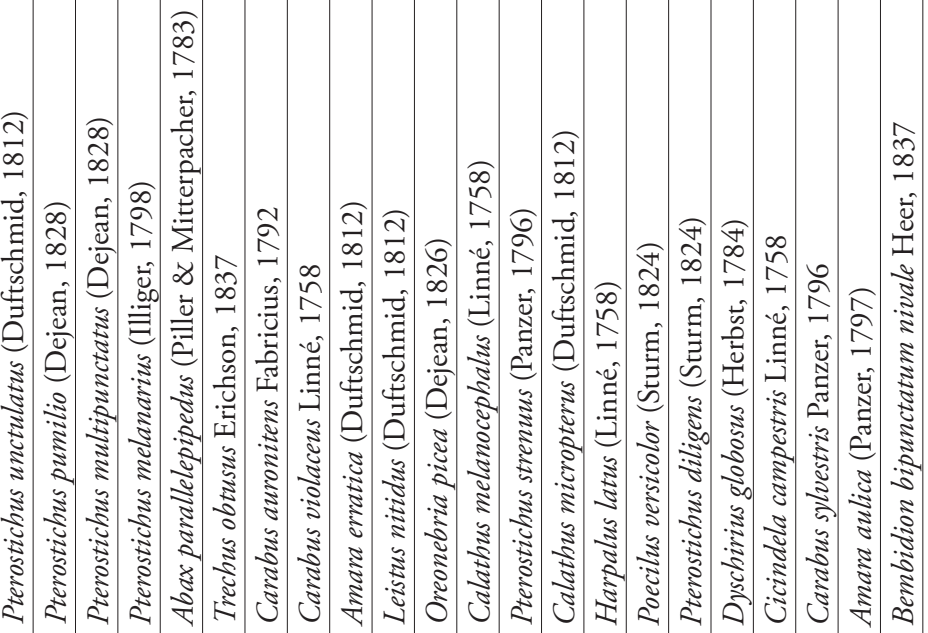




\begin{tabular}{|c|c|c|c|c|c|c|c|c|c|c|c|c|c|c|c|c|c|c|c|c|c|}
\hline$\infty \stackrel{\dot{\sigma}}{\dot{\omega}} \dot{\vec{b}}$ & & & $\stackrel{n}{\forall}$ & & $\stackrel{n}{0}$ & & & $\hat{\sigma}$ & & & & & & & & & & & & & $\stackrel{T}{*}$ \\
\hline$\wedge \begin{array}{l}\dot{1} \\
\dot{0} \\
\dot{m}\end{array}$ & $\stackrel{m}{m}$ & & $\stackrel{0}{\stackrel{2}{\sim}}$ & & 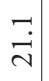 & $\dot{n}$ & $\tilde{n}$ & & & & & & & & & & & & & & $\stackrel{9}{\Lambda}$ \\
\hline ن & $\hat{\sigma}$ & & $\stackrel{?}{\forall}$ & & in & & & & $\vec{a}$ & & & & & & & & & & $\begin{array}{l}0 \\
\dot{0} \\
\dot{0}\end{array}$ & & $\exists$ \\
\hline 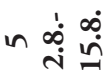 & $\stackrel{m}{m}$ & & $\stackrel{n}{*}$ & $\stackrel{n}{0}$ & & & $\stackrel{\infty}{=}$ & & $\vec{a}$ & & & & & & 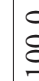 & & & & & & $\stackrel{\infty}{b}$ \\
\hline 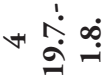 & $\begin{array}{c}m \\
\ddot{\sim}\end{array}$ & $\stackrel{\sim}{\sim}$ & $\stackrel{⿱ r}{\dot{m}}$ & & $\begin{array}{l}\infty \\
\dot{b} \\
\dot{m}\end{array}$ & $\stackrel{0}{\stackrel{0}{\beth}}$ & $\stackrel{\infty}{=}$ & & & & & $\begin{array}{l}n \\
\tilde{n}\end{array}$ & & & & & & & & & $\bar{\Xi}$ \\
\hline 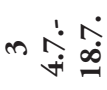 & $\stackrel{n}{n}$ & $\stackrel{\sim}{\sim}$ & $\stackrel{ \pm}{ \pm}$ & $\begin{array}{l}\infty \\
\ddot{n} \\
-1\end{array}$ & $\begin{array}{l}\infty \\
i \\
\sim\end{array}$ & $\begin{array}{l}\stackrel{0}{0} \\
\stackrel{-}{二}\end{array}$ & $\tilde{\tilde{v}}$ & $\begin{array}{r}n \\
\ddot{n}\end{array}$ & $\vec{a}$ & $\begin{array}{l}0 \\
\dot{\infty} \\
i\end{array}$ & $\widehat{\widehat{\vartheta}}$ & $\begin{array}{c}m \\
m \\
m\end{array}$ & $\begin{array}{l}0 \\
\dot{8} \\
0\end{array}$ & & & @ & & $\begin{array}{l}0 \\
\dot{8} \\
0\end{array}$ & & ?. & $\stackrel{1}{2}$ \\
\hline 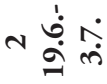 & $\begin{array}{l}m \\
\stackrel{\sim}{\sim}\end{array}$ & $\tilde{\text { î }}$ & $\stackrel{+}{\beth}$ & $\stackrel{-}{\vec{\lambda}}$ & $\stackrel{n}{n}$ & 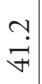 & $\stackrel{\sim}{\tilde{v}}$ & $\hat{\sigma}$ & $\begin{array}{l}\approx \\
\tilde{\forall} \\
\tilde{\sigma}\end{array}$ & $\vec{n}$ & స్తి & & & ?. & & & & & & & $\begin{array}{l}\infty \\
\ddot{v}\end{array}$ \\
\hline هُ & $\widehat{\grave{d}}$ & ì & $\widehat{\infty}$ & $\begin{array}{l}0 \\
i \\
i\end{array}$ & $\stackrel{m}{n}$ & $\begin{array}{l}0 \\
\stackrel{0}{-}\end{array}$ & $\tilde{\tilde{n}}$ & $\stackrel{n}{n}$ & $\stackrel{?}{\widehat{\imath}}$ & $\begin{array}{r}n \\
\stackrel{n}{-}\end{array}$ & ڤ્ & $\stackrel{m}{\stackrel{m}{m}}$ & & & & & $\begin{array}{l}0 \\
\dot{0} \\
0\end{array}$ & & & & ذे \\
\hline$\underline{\xi}$ & nి & $\stackrel{\vec{N}}{\sim}$ & $\widetilde{\sim}$ & $\approx$ & 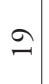 & 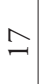 & $\beth$ & $\simeq$ & $\exists$ & $\Lambda$ & 6 & $n$ & $N$ & -7 & 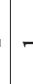 & -7 & - & - & -1 & & $-1 \begin{array}{c}\infty \\
\infty \\
n \\
n\end{array}$ \\
\hline
\end{tabular}

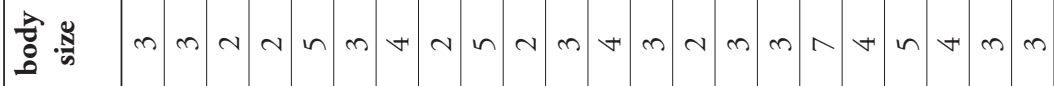

苛芦

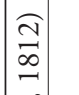



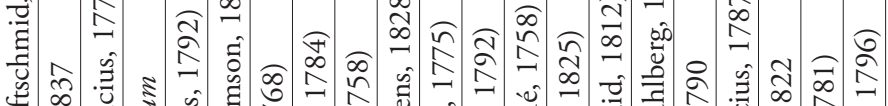

象泀

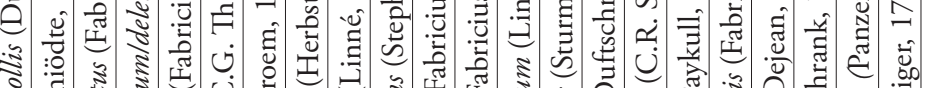

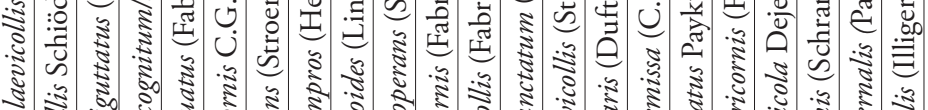

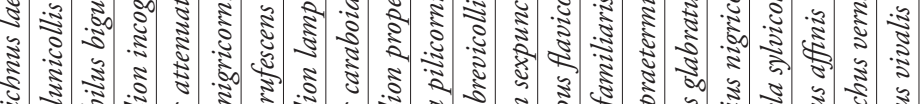

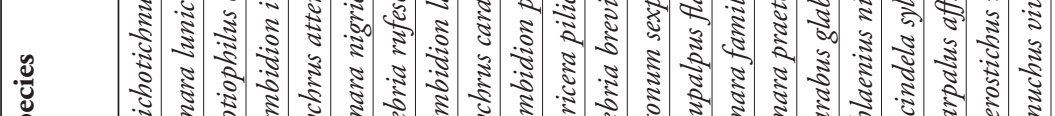

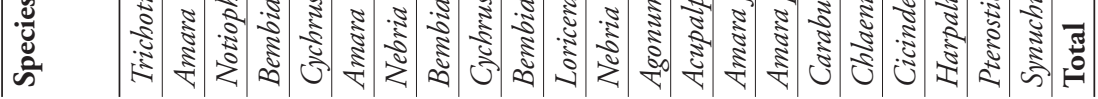




\section{Results}

In total, 13,585 specimens representing 47 species of carabid beetles were trapped over the sampling period (Table 2). The 10 most abundant species occurred throughout the whole altitudinal range of the study area.

General seasonal activity began with a maximum at the beginning of the study and showed a continuously decreasing tendency up until the end of September (Fig. 1). Focusing on individual numbers, the highest activity was in June, where $>50 \%$ of individuals were caught. In July, activity declined slowly, and in the second half of the sampling timespan, August and September combined, only 20\% of the total number of individuals were trapped.

The number of recorded species follows a similar trend: after a minute increase up to the first half of July, the number of species decreased. Mean species number per site was almost constant from June to the beginning of July, and then decreased up to the end of the study period (Fig. 2 a).

The extremes in beetle activity were greatest at sites above $1850 \mathrm{~m}$ a.s.l. relative to the other two altitude classes: the maximum in June was higher and the low activity from the second half of July until September was even more pronounced (Fig. 2 b). Differences between the activity phenology of low and mid-altitude classes were not significant ( $\mathrm{t}=-0.322, \mathrm{p}=0.753)$; however, mean activity of ground beetle species occurring at all elevations was earlier at higher altitudes than at the mid-altitude and lower sites $(\mathrm{t}=4.33, \mathrm{p}=0.001)$.

All species of which at least 10 individuals were caught had their activity peak in June or July, approximately two thirds of the species in June, and one third in July (Table 2).

Species can be divided into three groups according to their phenology: (1) The first and largest group of species shows quite a distinct activity peak in June (Fig. 3 a) and often a strong decline already occurring in July (e.g. P. multipunctatus, B. bipunctatum). Some of these species are almost absent in the second half of the year (A. erratica, B. bipunctatum). The strength of the spring activity peak may also be less pronounced (e.g. C. auronitens). (2) A second group of species shows a delayed activity peak (Fig. 3 b). In most cases, the magnitude of the peak was weaker than seen in the early species. In species with a delayed activity peak, there are also cases with absence in the second half of the year (A. aulica). (3) The third group is comprised of species that show no clear activity peak (Fig. 3 c), i.e. which are active over the entire sampling timespan. Only a few species fit into this latter scheme. Most of these are characterized by a weak peak in June, followed by a slow decline in activity. Some of the species exhibit a relatively high activity in the autumn (P. burmeisteri, A. paralellepipedus).

We were unable to find any significant relationship between phenological appearance and hindwing development of the species. Similarly, for body size no significant difference was found, although there is a weak trend of larger species appearing later in the year $(\mathrm{t}=1.61, \mathrm{df}=44, \mathrm{p}=0.114)$.

The sample-based accumulation curves of the first three sampling periods are almost identical at the start, and considerably steeper than the curves of subsequent 

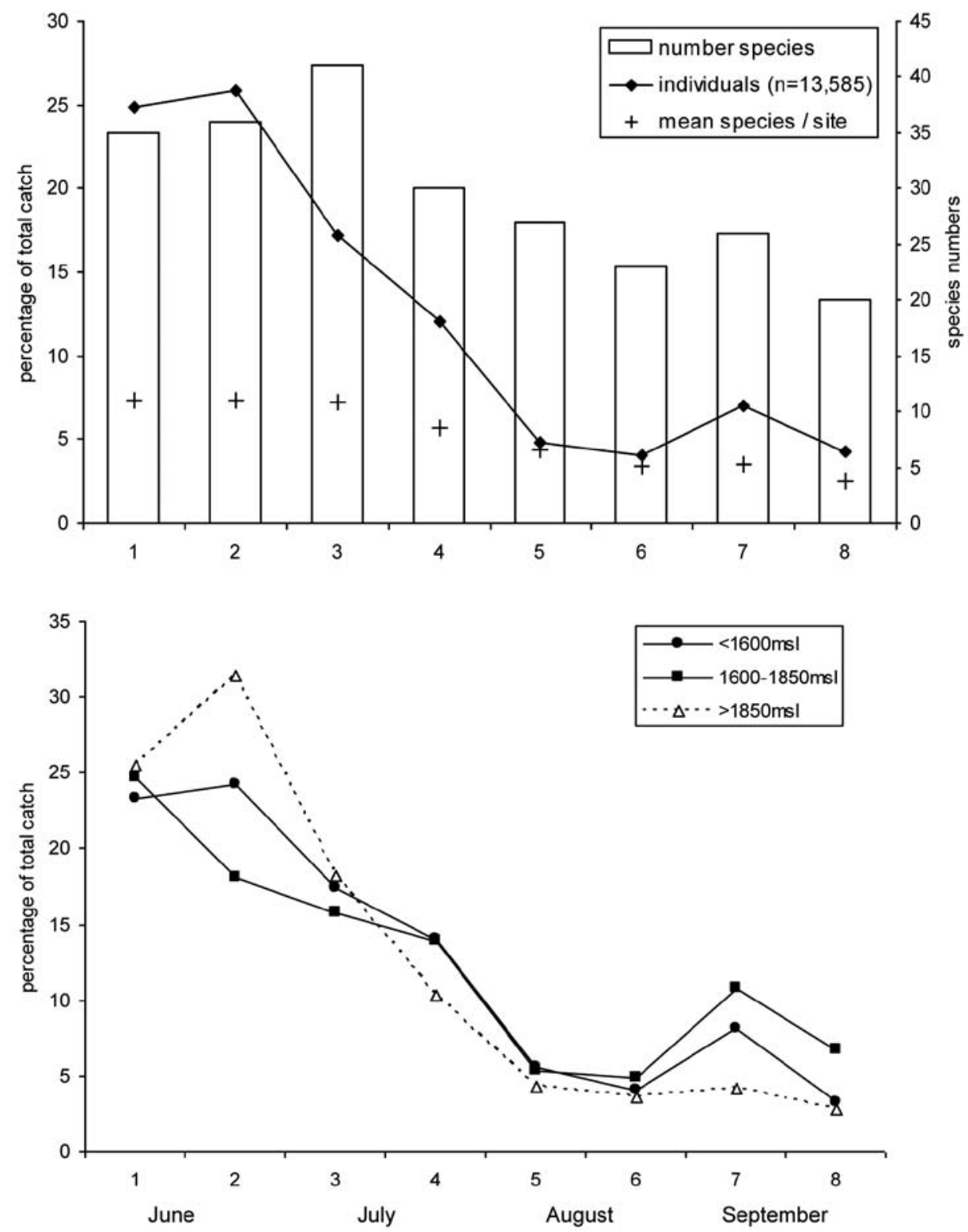

Figure 2. Phenology of ground beetles. a Overview over all sites. Number of individuals is converted to percentage of total catch. $\mathbf{b}$ Seperated for the three site classes of altitude. On the horizontal axis the sampling interval is given. For exact sampling periods, see Table 2.

periods and the curve based on the entire dataset (Fig. 4). After 25 samples, the curves of the first three periods split: the third period curve attains higher values, and the first and second period curves follow a similar trend. Decreasing overall activity after the spring peak is also discernible in the rarefaction curves: the curves for sampling periods 

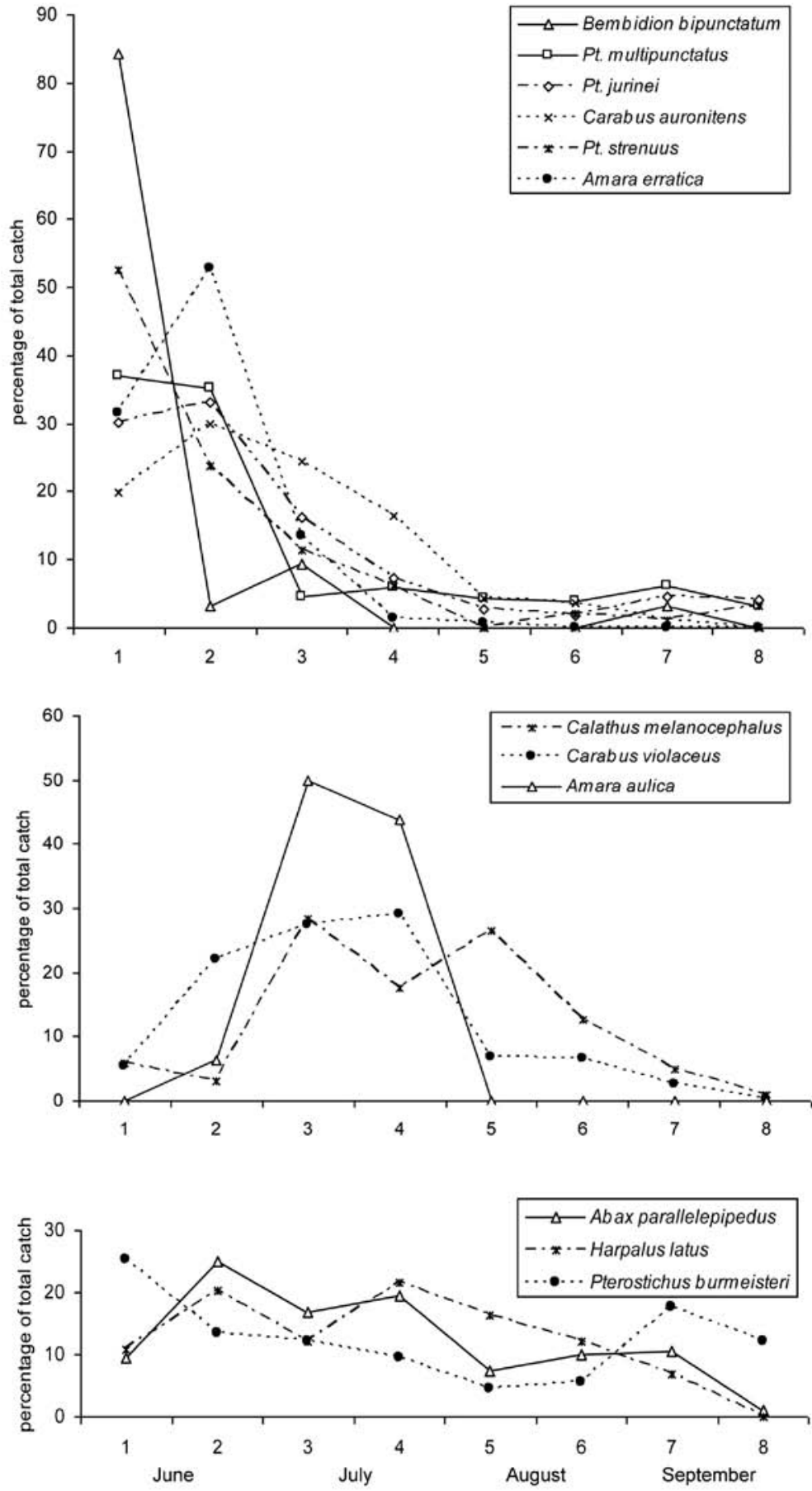

Figure 3. Phenology of single species. a Species with an early activity peak, b Species with a delayed activity peak and $\mathbf{c}$ Species without a clear activity peak. On the horizontal axis the sampling interval is given. For exact sampling periods, see Table 2. 


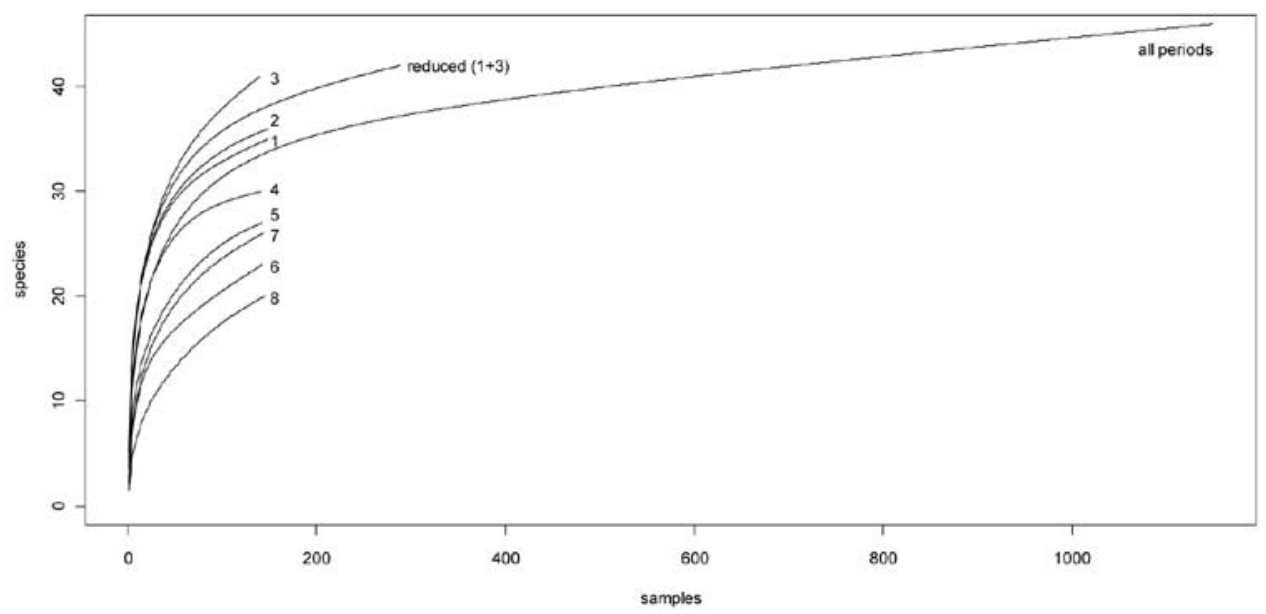

Figure 4. Sample-based rarefaction curves. Numbers refer to the different sampling periods.

4-8 are clearly below the curve for complete sampling (the curve for sampling period 4 is greater than the total sample curve at the start of the rarefaction process and then falls below it).

Table 3 illustrates the effects of a reduced sampling effort on observed species richness. While single sampling periods achieve a maximum of $65 \%$ of the total number of species over the entire sampling timespan, a combination of two early sampling periods can exceed $80 \%$ of the total amount of species (sampling periods 1 and 2 or 1 and 3). Best results are obtained when sampling effort is reduced to sampling periods 1 and 3. With the reduced datasets for sampling periods 1 and 3, 91.3\% of all species were detected. Per site, the mean quota was $83 \%$, and varied between 68.8 and $100 \%$. The quota of species detected was seen to be independent of altitude or number of specimens caught.

Classification showed that a reduced dataset (periods 1 and 3 only) represents the assemblage structure in a similar way to the complete dataset: All sites are grouped together until the last splitting, where they are divided as a result of sampling intensity (Fig. 5).

\section{Discussion}

The strong activity peak observed in our study at the start of the plant growing season has already been observed in many carabids in mountain regions, especially in subalpine and alpine ecosystems (Lang 1975; De Zordo 1979a, b; Refseth 1984; Janetschek, Meyer, Schatz and Schatz-de Zordo 1987; Gereben 1995; Ottesen 1996; Brandmayr et al. 2003b; Löffler and Finch 2005; Sharova and Khobrakova 2005). Depending on altitude, exposition and longitude, the weeks immediately after snow-melt are characterised by an activity peak in many species. The shortened plant growing season and 


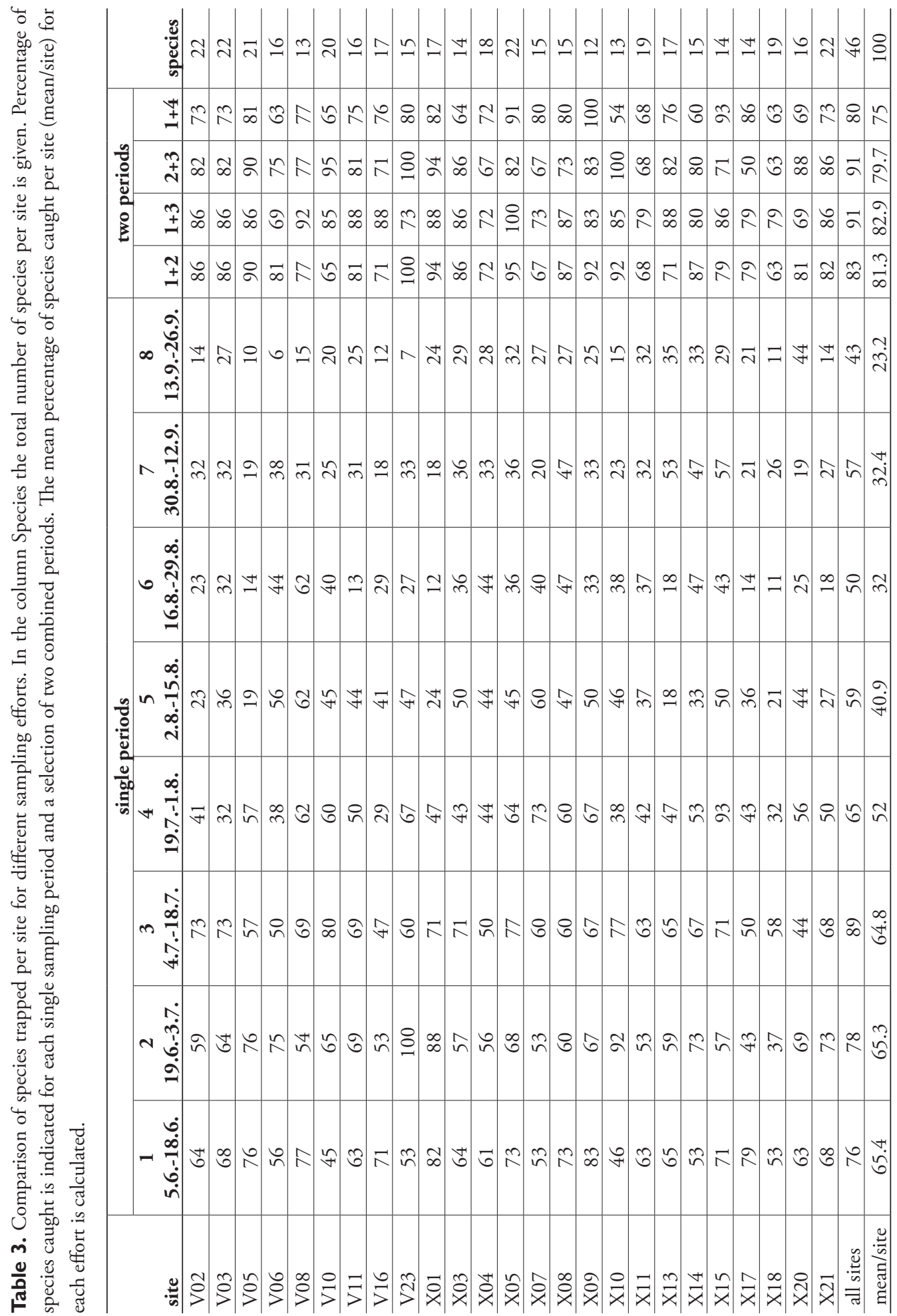




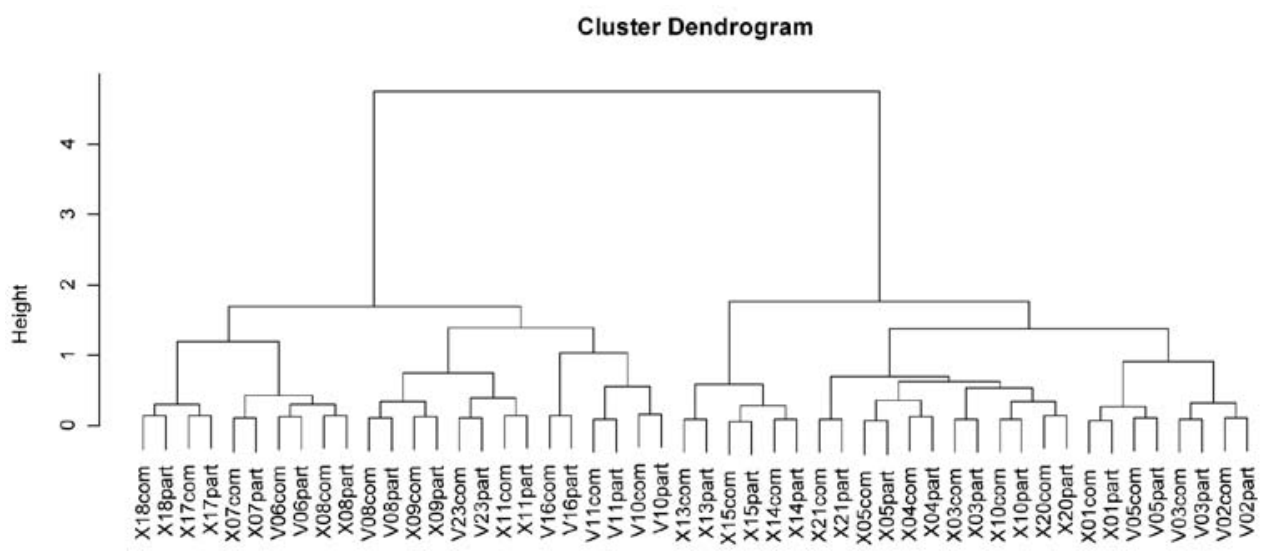

Figure 5. Dendrogram of sites with data from complete sampling (comp) and sampling periods 1 and 3 (part). The dendrogram is based on Bray-Curtis distances and uses Ward's minimum variance method.

the time in which the larvae are able to develop are given as an explanation for this. A fast start to reproduction in cool ecosystems is advantageous, as larval development takes longer under such conditions (cf. Paarmann 1966; Ferenz 1975). Food availability is another possible explanation; many swarming or flying insects (especially Diptera and Hymenoptera) are attracted to the white snow fields. After landing on these fields the insects are immobilised by the low temperatures. In most cases, ground beetles can pick them up live overnight or, later, as carcasses on snow fields after snowmelt. In these cases, some authors use the term "snow edge species", i.e. species which are adapted to cold and humid conditions and disappear very rapidly after snowmelt (Holdhaus 1954; Franz 1970; Marggi 1992; Brandmayr et al. 2005).

However, snow edge species (Marggi 1992), such as Bembidion bipunctatum nivale, are not the only species most often trapped after snow melt. Species with broader habitat preferences show increased activity during that time. Prevailing conditions after snow melt (open structure of vegetation and low "Raumwiderstand" sensu Heydemann 1956, the resistance of vegetation structure to the locomotory movement of a given species, high temperatures during sunshine combined with a high soil humidity) might be advantageous for several species.

While most papers focus on the abundant species, our data show that an early activity peak can also be observed for less abundant species. Ottesen (1996) made the same observation for carabids in alpine sites in Norway. However, this was not true for other groups of epigeic arthropods, as he observed an autumn activity peak for some species of staphylinids.

Although high spring activity was seen for all species, we observed differences between species: we were able to divide our species into three groups according to their phenological appearance. While the first group (early and strong spring activity peak) is most frequently described in mountain ecosystems, delayed spring activity has already been shown for some species by other authors (De Zordo 1979b; Refseth 1984), and a species 
without a strong activity peak was presented (Sharova and Khobrakova 2005). Our data do not give a clear indication of the reasons for the observed phenological differences among species, at least there were no simple relationships between the traits we tested.

The observed activity densities of species, with some species having a strong and early peak and others with a delayed peak led us to the conclusion that the best results can be expected by reducing the sampling to two periods at the beginning of the season. In fact, sampling periods 1 and 3 showed the highest average coverage of the sites' species richness, and the quota of species trapped was better than that suggested by Duelli et al. (1999) for the so-called standard minimum programme for lower altitudes. This means that for high altitudes our suggestion to reduce the sampling effort results in a more robust data set than similar approaches for lower altitudes, as the beetles' activity seems to be more concentrated within a shorter period in mountain ecosystems. The phenological data of other analyses conducted in different habitats from the upper montane zone upwards supports an approach that focuses on an early first sampling period and a delayed second (Lang 1975; De Zordo 1979a, b; Refseth 1984; Janetschek, Meyer, Schatz and Schatz-de Zordo 1987; Gereben 1995; Ottesen 1996; Löffler and Finch 2005; Sharova and Khobrakova 2005). Results of the classification procedure showed that with our reduction in sampling effort, community structure is represented well. A reasonably reduced sampling effort improves the chances of including carabid beetles in monitoring programmes in mountain areas, e.g. to evaluate the conservation status of habitats in Natura 2000 areas. If a reduction in sampling effort is inevitable, we recommend that the minimum sampling effort for carabids in mountain ecosystems should be two fortnightly sampling periods, the first immediately after snow melt and a second after a break of two weeks.

\section{Acknowledgements}

We would like to thank the Bayerischen Naturschutzfonds for financial support and the SMNK for carrying out the project. We thank Thomas Harry, Florian Raub and Ludger Scheuermann for their help during field work and Franziska Meyer for help in the laboratory. Special thanks goes to the cow-herder Helmut Radeck and his family for their hospitality. Many thanks to Gillian Cerbu and Linda Froome for language improvements.

\section{References}

Brandmayr P, Pizzolotto R, Scalercio S (2003a) Overview: Invertebrate Diversity in Europe's Alpine Regions. In: Nagy L, Grabherr G, Körner C, Thompson DBA (Eds) Alpine Biodiversity in Europe. Springer, Berlin, 233-238.

Brandmayr P, Pizzolotto R, Scalercio S, Algieri MC, Zetto T (2003b) Diversity patterns of Carabids in the Alps and the Apennines. In: Nagy L, Grabherr G, Körner C, Thompson DBA (Eds) Alpine Biodiversity in Europe. Springer, Berlin. 
Brandmayr P, Zetto T, Pizzolotto R (2005) arabidi per la valutazione ambientale e la conservazione della biodiversità: manuale operativo. Manuali e Linee Guida 34: 1-240.

Buddle CM, Beguin J, Bolduc E, Mercado A, Sackett TE, Selby RD, Varady-Szabo H, Zeran RM (2005) The importance and use of taxon sampling curves for comparative biodiversity research with forest arthropod assemblages. Canadian Entomologist 137: 120-127. doi: 10.4039/n04-040

De Zordo I (1979a) Ökologische Untersuchungen an Wirbellosen des zentralalpinen Hochgebirges (Obergurgl, Tirol). III. Lebenszyklus und Zönotik von Coleopteren. Österreichische Kommissionsbuchhandlung, Innsbruck, 9-131 pp.

De Zordo I (1979b) Phänologie von Carabiden im Hochgebirge Tirols (Obergurgl, Österreich). Ber nat-med Ver Innsbruck 66: 73-83.

den Boer PJ, van Dijk TS (1996) Life history patterns among carabid species Tijdschrift voor Entomologie 139: 1-16.

den Boer PJ, van Dijk TS (1998) The relevace of life-history theory for carabid species of Western Europe. In: Baumgärtner J, Brandmayr P, Manly BFJ (Eds) Population and Community Ecology for Insect Management and Conservation. Balkema, Rotterdam, 193-203.

Duelli P, Obrist MK, Schmatz DR (1999) Biodiversity evaluation in agricultural landscapes: above-ground insects. Agriculture Ecosystems \& Environment 74: 33-64. doi: 10.1016/ S0167-8809(99)00029-8

Dufrene M, Legendre P (1997) Species assemblages and indicator species: The need for a flexible asymmetrical approach. Ecological Monographs 67: 345-366.

Fadl A, Purvis G (1998) Field observations on the lifecycles and seasonal activity patterns of temperate carabid beetles (Coleoptera : Carabidae) inhabiting arable land. Pedobiologia 42: $171-183$.

Ferenz H-J (1975) Anpassung von Pterostichus nigrita F. (Col., Carab.) an subarktische Bedingungen. Oecologia 19: 49-57. doi: 10.1007/BF00377589

Franz H (1970) Ökologie der Hochgebirge. Ulmer, Stuttgart, 494 pp.

Gereben BA (1995) Cooccurrence and Microhabitat Distribution of 6 Nebria Species (Coleoptera, Carabidae) in an Alpine Glacier Retreat Zone in the Alps, Austria. Arctic and Alpine Research 27: 371-379. doi: 10.2307/1552030

Gesellschaft für Angewandte Carabidologie (2009) Lebensraumpräferenzen der Laufkäfer Deutschlands. Wissensbasierter Katalog. Angewandte Carabidologie Supplement V.

Gotelli NJ, Colwell RK (2001) Quantifying biodiversity: procedures and pitfalls in the measurement and comparison of species richness. Ecology Letters 4: 379-391. doi: 10.1046/j.1461-0248.2001.00230.x

Haslett JR (1997) Mountain ecology: organism responses to environmental change, an introduction. Global Ecology and Biogeography Letters 6: 3-6. doi: 10.2307/2997522

Heydemann B (1956) Die Biotopstruktur als Raumwiderstand und Raumfülle für die Tierwelt. Verhandlungen der Deutschen Zoologischen Gesellschaft 47: 332-347.

Höfer H, Harry I, Hanak A, Urban R (in press) Das Projekt Einödsberg - Begleituntersuchungen zur geänderten Weidenutzung auf einer Allgäuer Alpe. Andrias 18.

Höfer H, Harry I, Hanak A, Urban R, Kraft B (2008) Die Einödsberg-Alpe - Ein Brennpunkt der Artenvielfalt. Natur und Museum 138: 224-231. 
Holdhaus K (1954) Die Spuren der Eiszeit in der Tierwelt Europas. Universitätsverlag Wagner, Innsbruck, $493 \mathrm{pp}$.

Hosoda H (1999) Altitudinal occurrence of ground beetles (Coleoptera, Carabidae) on Mt. Kurobi, central Japan, with special reference to forest vegetation and soil characteristics. Pedobiologia 43: 364-371.

Hutchison MAS (2007) Seasonality and life histories of two endemic New Zealand carabid beetles (Coleoptera : Carabidae): Mecodema oconnori Broun and Megadromus capito (White). New Zealand Journal of Zoology 34: 79-89. doi: 10.1080/03014220709510066

Janetschek H, Meyer E, Schatz H, Schatz-de Zordo I (1987) Ökologische Untersuchungen an Wirbellosen im Raum Gurgl unter Berücksichtigung anthropogener Einflüsse. In: Patzelt G (Ed) MaB - Projekt Obergurgl. Universitätsverlag Wagner, Innsbruck, 283-315.

Kobayashi S (1974) The species-area relation I. A model for discrete sampling. Researches on Population Ecology 15: 223-237. doi: 10.1007/BF02510669

Lang A (1975) Koleopterenfauna und -faunation in der alpinen Stufe der Stubaier Alpen (Kühtal). Österreichische Kommissionsbuchhandlung, Innsbruck, 81 pp.

Larsson SG (1939) Entwicklungstypen und Entwicklungszeiten der dänischen Carabiden. Entomologiske Meddelelser 20: 277-560.

Lederbogen D, Rosenthal G, Scholle D, Trautner J, Zimmermann B, Kaule G (2004) Allmendweiden in Südbayern: Naturschutz durch landwirtschaftliche Nutzung. Landwirtschaftsverlag, Münster, pp.

Lindroth CH (1949) Die Fennoskandischen Carabidae III. Allgemeiner Teil. 1-911. pp.

Löffler J, Finch O-D (2005) Spatio-temporal Gradients between High Mountain Ecosystems of Central Norway. Arctic, Antarctic, and Alpine Research 37: 499-513. doi: 10.1657/1523-0430(2005)037[0499:SGBHME]2.0.CO;2

Lomolino MV (2001) Elevation gradients of species-density: historical and prospective views. Global Ecology and Biogeography Letters 10: 3-13. doi: 10.1046/j.1466822x.2001.00229.x

Lys JA, Nentwig W (1991) Surface-Activity of Carabid Beetles Inhabiting Cereal Fields - Seasonal Phenology and the Influence of Farming Operations on 5 Abundant Species. Pedobiologia 35: 129-138.

Marggi WA (1992) Faunistik der Sandlaufkäfer und Laufkäfer der Schweiz (Cicindelidae \& Carabidae) Coleoptera., Neuchâtel, 478 pp.

Matalin AV (1997) Peculiarities of carabid (Coleoptera, Carabidae) spatial- temporal differentiation in steppe zone. Zoologichesky Zhurnal 76: 1035-1045.

Oksanen J, DKindt R, Legendre P, O’Hara B, Simpson GL, Solymos P, Stevens MHH, Wagner H (2008) vegan: Community Ecology Package. 1.15-0 ed, pp.

Ottesen PS (1996) Niche segregation of terrestrial Alpine beetles (Coleoptera) in relation to environmental gradients and phenology. Journal of Biogeography 23: 353-369. doi: 10.1046/j.1365-2699.1996.00971.x

Paarmann W (1966) Vergleichende Untersuchungen üiber die Bindung zweier Carabidenarten (Pterostichus angustatus Dft. und Pterostichus oblongopunctatus F.) an ihre verschiedenen Lebensräume. Zeitschrift der Wissenschaftlichen Zoologie 174: 83-176. 
Paarmann W (1979) Ideas about the evolution of the various annual reproduction rhythms in carabid beetles of the different climatic zones. Miscellaneous Papers 18: 119-132.

R Development Core Team (2008) R: A language and environment for statistical computing. 2.8.0 ed. R Foundation for Statistical Computing, Vienna.

Rainio J, Niemela J (2003) Ground beetles (Coleoptera: Carabidae) as bioindicators. Biodiversity and Conservation 12: 487-506. doi: 10.1023/A:1022412617568

Refseth D (1984) The life cycles and growth of Carabus glabratus and C. violaceus in Budalen, central Norway. Ecological Entomology 9: 449-455. doi: 10.1111/j.1365-2311.1984. tb00843.x

Riddick EW, Mills NJ (1995) Seasonal Activity of Carabids (Coleoptera, Carabidae) Affected by Microbial and Oil Insecticides in an Apple Orchard in California. Environmental Entomology 24: 361-366.

Sharova IK, Khobrakova LT (2005) Features of the life cycles of Pterostichus montanus (Motschulsky, 1844) and Carabus loschnikovi (Fischer-Waldheim, 1822) (Coleoptera, Carabidae) in conditions of the mountain taiga belt in the Eastern Sayan. Biology Bulletin 32: 27-37. doi: 10.1007/s10525-005-0006-5

SMNK: Projekt Einödsberg. http://www.einödsberg.de/ [accessed 22.11.2009].

Sota T (1996) Altitudinal variation in life cycles of Carabid beetles: Life- cycle strategy and colonization in alpine zones. Arctic and Alpine Research 28: 441-447. doi: 10.2307/1551855

Szyszko J, Vermeulen HJW, Klimaszewski K, Abs M, Schwerk A (2000) Mean Individual Biomass (MIB) of ground beetles (Carabidae) as an indicator of the state of the environment. In: Brandmayr P, Lövei GL, Zetto Brandmayr T, Casale A, Vigna Taglianti A (Eds) Natural history and applied ecology of carabid beetles. Pensoft, Sofia, 289-294.

Thiele H-U (1977) Carabid beetles in their environments. A study on habitat selection by adaptions in physiology and behaviour. Springer, Berlin Heidelberg New York, 367 pp.

Traugott M (1998) Larval and adult species composition, phenology and life cycles of carabid beetles (Coleoptera : Carabidae) in an organic potato field. European Journal of Soil Biology 34: 189-197. doi: 10.1016/S1164-5563(00)86661-3

Ugland KI, Gray JS, Ellingsen KE (2003) The species-accumulation curve and estimation of species richness. Journal of Animal Ecology 72: 888-897. doi: 10.1046/j.13652656.2003.00748.x 